821.163.41.09-32 Лазаревић Л. https://doi.org/10.18485/kij.2019.66.2.5

МИЛАН Д. ВУРДЕЉА*

Универзитет у Београду

Филолошки факултет, докторанд
Оригинални научни рад

Примљен: 10. 10. 2019.

Прихваћен: 02. 12. 2019.

\title{
ИЗНУЂЕНИ ЗАЗОР ОД ДРУГОГ: ОСВРТ НА ИМАГОЛОШКЕ АСПЕКТЕ ПРИПОВЕДАКА ЛАЗЕ ЛАЗАРЕВИЋА**
}

\begin{abstract}
Разуђена предметност имагологије као нарочито аутономне дисциплине компаратистике, у овом раду огледаће се у испитивању различитих литерарних проблема у изабраним приповеткама Лазе Лазаревића. Са претпоставком да се иза националних, класних и других имажа у фикцији Лазе Лазаревића крију битни слојеви значења, рад ће, поред осталог, скренути пажњу на поступке којима се слика другост, а који представљају незанемарљив удео у поетици српског реалистичког писца.
\end{abstract}

Кључне речи: Лаза Лазаревић, приповетка, слика другог, национални идентитет, матична култура, туђина.

Уводне напомене. Због усложњених модела реалистичке поетике и све виднијег изналажења нових приступа унутрашњем свету књижевних јунака, најбољи део прозе Лазе Лазаревића се, с пуним правом, узима за претходницу модерног израза, односно систематизује се у оквиру такозване дезинтеграције реализма (Живковић 1994: 170-180). Сходно овоме, Лазаревиће приповетке се показују погоднима за сасвим диверзна истраживања. Најпре се намећу она која би фаворизовала психолошке димензије његових ликова, запретеност њихових доживљаја, односно силовито антиципирану проблематику модерног идентитета. Од оваквог промишљања неодвојиве су појаве симболизације прозе, алегоричности и замућивања common sense начела које је својствено класичном реалистичком маниру. Ипак, Лазаревићеве приповетке и даље у много чему зависе од оне реалистичне конкретности културно-историјског тренутка у којем настају, о чему прецизније пише Горана Раичевић (Раичевић 2007: 7-51).

*milan.vurdelja93@gmail.com

** Рад је део научног пројекта „Поетика српског реализма” (178025), финансираног од стране Министарства просвете, науке и технолошког развоја. Пројектом руководи др Душан Иванић, професор емеритус. 
Одатле је у њима могуће тумачити релативно стабилне „слике о другом” (махом именоване хетероимажима), а које најчешће прати закулисно ${ }^{1}$ образовање слике о себи (аутоимаж), при чему су све оне засноване на националним, социјалним, или родним представама које происходе из фикционалних идентитета ликова. Као критичко-аналитички правац унутар компаратистике, имагологија настоји продрети у смисао замршених комуникација посредством обликованих стереотипа који су успостављени између колективних, односно појединачних идентитета. У својој, сад већ незанемарљивој историји развоја, имагологија у многоме превазилази оригиналне замисли Фернанда Балденспержеа и Пола Ван Тигема, те се промовише у нарочито интердисциплинарну истраживачку делатност. Речима Зорана Константиновића, „слике произилазе из словних знакова и оне сведоче пре свега о одређеном стању културе” (Константиновић 2006: 11).

Читав овај, релативно развијенији уводни екскурс, нужан је у овом раду из разлога отклањања евентуалне сумњичавости поводом чињенице да се Лазаревићеве приповетке показују не само садржајнима, већ и изазовнима за имаголошка разматрања, а чему ће посведочити даља анализа.

1.

Лазаревићева приповетка „Швабица” дата је у форми приређеног рукописа епистоларног карактера. Својом романтичарском потком располућивања свести субјекта у сусрету са феноменом љубави, она у исти мах доноси и пародично третирање поменутог комплекса, и то из перспективе самог састављача тринаест епистола - главног јунака, Мише. С овим је у вези и „реторика одгоде” (Милосављевић Милић 2014: 95-110) која на површини рефлектује јунаково свесно ниподаштавање кроз романтичарску призму преломљених вредности жртвовања и повиновања драгој, а која у својој позадини сведочи о немогућности јунакове воље да надиђе импулсивност осећања. Притом, патетичан и високопарни доживљај драге бива у одређеној мери супституисан такође узвишеним (из јунакове перспективе) потчињавањем мисаоном и духовном конструкту отаџбине. Негде између ова два проблема, безмало кроз читаву приповетку врши се успостављање постојаних стереотипних виђења, због чега се њена целокупна вредност, или крајњи естетски домет, боље описује увођењем имаголошког метода у тумачење.

Овакво опредељење подразумева да не би требало заобићи ни очевидну интервенцију у наслову. Огољеном лексемом „Швабица” писац не само да наговештава извесну јунакињу, известан женски карактер у основи приче, него и провоцира читаоца да се окрене негативном расуђивању, па да се запита зашто у наслов није стављена ординарна лексема „Немица”. Различити имаголошки

${ }^{1}$ По питању овог односа, присећамо се упечатљивог запажања Данијела Анри Пажоа, вероватно најистакнутијег представника француске имагологије: „Огледајуће се претвара у огледало” (Pageaux 2009: 148) 
приступи који у својој радикалности каткад иду предалеко одмах би се „окомили" на пишчеву, дакле ауторску свест, и тражили разлоге због којих се као наслов приповетке узима типично српска пројекција једног етничког спецификума (Шваба) у целокупну нацију (Немац), која притом за собом повлачи различите конотације - од хуморне до пејоративне. Биће да је стварно покриће наслова чисто литерарне природе, да дакле происходи из смисла приповедачевог односа према насловној јунакињи.

Затим ваља приметити како Миша у својим писмима ословљава адресата. Обично су то вокативи: „брате” или „побратиме”. Узимајући у обзир релеванцију коју у српској култури има ова родбинска, односно псеудородбинска релација, могуће је закључити да Миша у своме саговорнику, премда готово ништа не знамо о њему, намерно не види само некога ко ће примати извештаје о његовим искуствима у иностранству, већ и ону домаћу фигуру која завређује ексклузивну квалификацију побратима. Осим реченог, овакво фреквентно ословљавање адресата може аргументовати блискост са њиме, па и претпостављену искреност у сачињавању писама, или несигурност и усиљену симпатију.

Миша такође поседује потребу да са побратимом увек изнова коментарише „њу”, а онда и „њен” свет. Из садржаја писама бива јасно како је Миша скоро па затечен у „њеној” другости. По среди је, наиме, његово двоструко дистанцирање: колико од жене чија га појава заноси и држи у непрестаној узнемирености, толико и од њеног матичног окружења, у оквиру ког он не налази адекватну афирмацију и у које се не успева идентитетски инкорпорирати. Симптом позиције аутсајдера нарочито је садржан у поменутој, наизглед безначајној али честој употреби заменице „она”, којом се поткрепљује Мишина немогућност да Анин свет доживи и као могуће поље сопственог духовног остварења. Шта га спречава у томе? Шта додатно хипертрофира ту другост коју он не успева да преброди?

То је, у првом реду, упућеност на немачко географско подручје, то јест удаљеност од домовине, али још и више утицај немачке културе, којој дакле Ана припада, а у којима Миша, из сопствене перспективе, странствује. Текст нам на многим местима аргументује ову чињеницу. Одмах, у првом писму, Миша трпезарију у којој дели свакодневицу са пријатељима и Аном, назива „нашим интернационалним земљиштем" (Лазаревић 1958: 43). Садржај наредних писама указује на подељеност ликова у националном погледу: студенти и гимназисти су руског, српског, румунског и немачког порекла. Низ ситуација које Миша побратиму предочава, потврђује, међутим, културолошку ексклузивност коју повлачи за собом немачки национални простор, будући да се у његовом окриљу и долази до дотицаја између свих других.

Са становишта имагологије, овде је важно приметити да Миша устврђује како се на поменутом „интернационалном земљишту” сви осећају „као у својој coби” (Ibid: 43). Чини се да се пријатност боравка у туђини повећава у дотицају странца са другим странцима, односно дошљацима, без обзира на другостепену националну разлику међу њима, а као последица заједнички заузете позиције 
спрам доминирајуће, у овом случају немачке културе. Описани психолошки феномен у приповеци је продубљен дочаравањем атмосфере интернационалног клуба, тј. трпезарије. Њени посетиоци се неформално друже, разговарају, свирају клавир и, повремено, шаљиво коментаришу заједничку националну хетерогеност. Ипак на основу моде и манира којима се повинују (Попеску, нпр, највише свира немачке партитуре и Телове увертире), уочљива је супремација немачке културе, а у одређеним тренуцима и њена, условно казано, агресивна самопромоција. Зато за Немца у друштву, Миша пише да стално говори о „силном немачком царству” (Ibid: 47), што Туманов, Рус дакле, испрати ироничном опаском о „снажној немачкој природи” (Ibid: 47). Ипак, банална чињеница да је немачки језик прва опција за споразумевање у кружоку говори у прилог његовој подразумеваној изузетности.

Додатно, постојани мотив националног опредељења испрва је везан за јунака, кроз његово посредно негативно одређење Ане: „Шта би рекли моји, шта пријатељи ? [...] Прво, није ни Српкиња, можда ни лепа, а сирота” (Ibid: 45). Краћа анализа окружења о којем пише Миша била нам је овде потребна како би се акценат ставио на компликоване међуодносе три семантичка члана: Мише, Ане и Мишине отаџбине, с обзиром на то да су они извор централне проблематике Швабице. Миша je, par excellence, репрезент оне патничке свести која се ломи под друштвено условљеним конструктом, каква је категорија нације и њеног директног идеолошког корелата: отаџбине. Романтичарска призма кроз коју је могуће сагледавати овај проблем, да се повезати са културолошком димензијом романтизма коју обележава интериоризовани сукоб, погубан:

„Романтизам доиста изражава на умјетничком плану [...] природу грађанског човјека [...] Грађанин се и у умјености појављује као раздрта и подвојена личност. Он ће тражити излаз из ове 'несретне свијести' било у реалистичкој критици друштва било у индивидуалистичкој побуни, са правом да сам одреди своју егзистенцију, свој усуд” (Supek 1986: 92)

Да бисмо расветлили Мишину духовну парализованост, потребно је назначити да се код других актера приче, премда они такође бивају одређени истим конструктима, не осећа горчина ове условљености, да се чак неки међу њима, Туманов и Дон Карлос на пример, дају и у комичној или карикатуралној визури. Узрок ове Мишине издвојености, ове „трагедије разума” (Раичевић 2007: 92), није његова априорна ксенофобија спрам немачког националног идентитета, већ се пре може говорити о изнуђеном зазору од стране културе која није у стању да разуме ону из које јунак долази. Тај шум у комуникацији и тензија на линији немачка-српска култура претрајава кроз читаву приповетку, те постаје главни разлог Мишиног потресног уклањања од могућности љубавне среће са Аном. Кључне су у овом смислу епизоде у којима Ана показује фатално непознавање српског, и шире словенског културног идентитета, иако показује добру вољу и настоји да их уз Мишину помоћ упозна.

Отклон од словенства изражен је још више у случају госпођице Кларе Ведел, фигуре из Аниног окружења, која јунаку чини велику непријатност потпуно 
нетачним и непримереним довођењем у везу мађарског и српског језика. Побратиму поводом овог догађаја Миша каже да се није „срдио” и наставља: „Ти знаш да Србин на страни, а особито у класичној Немачкој мора огуглати на ова питања...” (Лазаревић 1958: 66). Чини се, ипак, да Миша није сасвим „огуглао” на овакве предрасуде, поготово јер се у целини његовог писања не открива никаква супериорност странца навикнутог на неразумавање с друге стране. Пре ће бити да је овде уведена и нека дубља, унутрашња иронија, којом се Миша сам себи имплицитно подсмева.

Суштинска негостољубивост немачког окружења узрокује и нешто агресивније Мишине иступе које је старија критика доводила у везу са ксенофобијом. Међутим, неки његови хуморно интонирани испади показују да се ради о сложенијем стању лика које га приближава феномену обескорењености, будући да је његова прва особина неснађеност не само у новој средини, него и у властитој кожи. Таква је сцена у којој Миша дрчно наводи дромбуљу као свој инструмент и потом збуњеним Немцима објашњава да је реч о некој врсти флауте. Имаголошким речником саопштено, чини се да се у овој сцени открива Мишино аутоиронично разрачунавање са метаимажом - сликом за коју претпостављамо да је припадници друге заједнице, у овом случају националне, имају о нама. Назире се и оно што би се лапидарним психолошким речником одредило као одбрамбени механизам и покушај да се немачке културне предрасуде изврну руглу.

Осмо писмо доноси најзначајнију илустрацију Мишиног односа према немачкој култури. У питању је сцена сукоба са Максом, којом се раскринкава потискивано гађење које Миша има поводом разлика између српског и немачког доживљаја јунаштва. Неделотворан и неуспешан на љубавном плану, Миша као да пролази кроз прснуће своје подсвести, и без објективног повода напада Макса који се вратио из једног двобоја. Горана Раичевић ово оправдано повезује са пројекцијама које о себи самом, на вишем нивоу, Миша прави: „Hоmо balcanicus je homo heroicus и његова визија храбрости и одбране части не задовољава се симболичким гестовима „пуштања крви” - његов традицијски код тражи саможртвовање ради вечног живота и вечне славе” (Раичевић 2007: 91). У складу са таквим, ненаметљивим али присутним аутоимажом, мотивација за Мишин сукоб са Максом поткрепљена је исказима Немца: „Само не тако српски...варварски - рече он [...] Serbe - рече он подругљиво” (Лазаревић 1958: 79). Делимично испровоциран Мишиним слабо пририкривеним гађењем, Немац оваквим исказима узрокује физички сукоб, рачунајући на супарникову рањивост када је реч о његовој домовини. Враћамо се, дакле, Мишиним пројекцијама о сопственом српству.

Речене пројекције у редовним навратима искрсавају у његовој свести. Он их у писмима побратиму саопштава врло живо, без обзира на то да ли их поткрепљује додатним рефлексијама или не. Оне одиста функционишу као рестриктивни конструкт, као у примеру: „Ја се нагох њојзи. У исти пар сину ми као муња кроз главу: Швабица, сирота, моја мати, Србија. Скочим, и не уздајући се у својој глас, без збогом одем у своју собу" (Ibid: 60). Симптоматична је Мишина 
жеља да и Ану упозна са српским обичајима и епском поезијом. Њоме се разоткрива неспретан и узалудан његов напор да се превазиђе категорија другости, од које у његовом доживљају толико зависи Анина личност.

У финалу приповетке, на основу парафразиране преписке са породицом, Миша установљава немогућност иницијације Ане у властиту културу, иако се чини да би она и на то пристала. Како сам наратор каже: „Писмо сестрино бацило ме је тамо одакле се Ана не види" (Ibid: 86). Менталне и психолошке пројекције отаџбине у Мишином случају очито нису тако безазлене. Овде се ваља обратити студији Национални идентитет Ентонија Смита, у којој се указује на дистинкцију између „западног” и „незападног” етничког модела, при чему се за други устврђује да нација у већој мери функционише као фиктивна „натпородица” (Smit 1998: 26). Када Смит пише о национализму, позивајући се на типологију Ханса Кона, он издваја источњачку верзију национализма као „органску и мистичну” (Smit 1998: 129). Наведена запажања дају се применити на расветљавање Мишиног лика, што би значило да се он приклања источњачком моделу нације, односно национализма, и да сходно томе запада у проблем повиновања, или чак жртвовања вишој инстанци - отаџбини као мајци.

Тада, напослетку, постаје јасније у чему је можда кључни проблем Мишиног идентитета. Тежећи да се промовише у модерни индивидуум оног времена, дакако западноевропског типа, који на љубав гледа трезвено, депатетизовано и антиромантичарски, он истовремено баштини у себи источњачку традицију мистичног доживљаја матичне земље, културе и језика. На овој копчи се, дакле, образује двострука контрадикторност, будући да се мешају и две раздвојена поља: интимно (искуство љубави) и политичко (искуство нације). Иста копча мора пући, због чега Миша страда.

Приповетке „Вертер” и „Ветар” на другачији начин залазе у предметност имагологије, те за разлику од „Швабице” ово не делује толико транспарентно. Потребно је поменути како се и у другим насловима из корпуса Лазаревићевих најпознатијих приповедака налазе слике о различитим нацијама или етничким групама (Јевреји, Французи, Турци, Черкези²), или је пак заступљено тематизовање

\footnotetext{
${ }^{2}$ У оквиру детаљнијих имаголошких истраживања Лазаревићевих текстова, свакако би ваљало размотрити зашто се у њима Јевреји именују „Чифутима”, или зашто се у приповеци Све ће то народ позлатити Черкези узимају за пословични пример насиља и садизма. Проблем именовања етничких група, заједно са именовањем особина које им се стереотипно, или макар по инерцији приписују, такође залази у важно подручје имаголошког читања, оно које се тиче испитивања „лексичке мреже присутне у текстовима, појмовног и афективног арсенала лексичких мрежа које припадају већој заједници од појединачног читаоца" (Гвозден 2001: 218). Нама се чини да је ова врста именовања последица специфичног историјског периода за балканско, па и европског поднебље из којег Лазаревић долази. Деветнаести век још увек не види овакве квалификације као вид расистичког дискурса, што треба узети у обзир при успостављању савремене визуре за сагледавање проблема.
} 
отаџбине, па и државе као битних феномена одређене историјске стварности са којом Лазаревић комуницира. Овде се, у првом реду, мисли на приповетке „Све ће то народ позлатити” и „Школска икона”. У првој су, на пример, знаковита опозитна очекивања која према држави имају два кључна актера догађаја, Благоје казанџија и капетан Јеличић, а која се директно рефлектују на проблем ратних инвалида, дакле једне друштвене маргине. Док Благоје своју земљу види пре као отаџбину, те одатле од ње очекује срчанију бригу о ратним инвалидима, капетан покушава рационалније увидети механизме на којима почива држава - и на овом месту се успоставља дихотомија.

Уплитање мотива отаџбине као традицијског супстрата за државу, осећа се и у социјалном груписању ликова у „Школској икони”, где се изнова проблематизује сустицање новог са старим, нове интелигенције са постојаним патријархалним етосом, симболички обједињеним у задрузи. Наведени елементи су, међутим, још за нијансу суптилнији него што је то случај у до сада издвојеним приповеткама, из ког разлога се они у овом раду, а сходно његовим формалним ограничењима, неће поближе анализирати.

Плодоносно је имати у виду да Лазаревић радо уноси представе које једне о другима генеришу ликови различито позиционирани на друштвеној лествици. Уобличавање лика војног лица, као репрезента специфичне социјалне групе, у „Вертеру” је делимично засновано на стереотипима, због чега има смисла активирати имаголошки метод, ако се исти разуме у ширем значењу од првобитног, оног које је имало интересовања само за тумачење слика о туђој нацији. Визура се, дакле, помера и на конструктивизам у темељу социјалних односа у заједници. Спољашњост поручника Васиљевића (његова наглашена стаситост) и истицање његових навика (увртање брчића, парадирање са сабљом о боку и држање до „официрске части”) комплементарни су увреженим, донекле стереотипним и вицкастим представама о војним лицима.

Слично је грађење лика професора Недића, Лазаревићевог нашијенца који је овога пута наклоњен немачкој култури, то јест својој визији исте, којој, наиме, признаје цивилизацијски примат. Недић је, иницијално, хуморно окарактерисан (,Чак и у шпагу од прслука наћи ћете му какав додатак Аугзбуриким новинама или депешу Политичке кореспонденције” (Лазаревић 1958: 184)). Оба лика су, према томе, више-мање карикатурално образована, што иде у прилог чињеници да су стереотипи у књижевном тексту често „место повишене реторике, увек појачани, курзивирани” (Вукићевић 2011: 47). Спорадични доживљаји наратоpa, заједно са неколиким његовим коментарима, али и репликама других ликова (нарочито Младена и Катанића, у даљем току приповетке) такође се оцртавају на имаголошком хоризонту.

Од почетног кадрирања при увођењу бањских гостију, примећује се ауторова намера да изнесе палету социјалних типова оне деветнаестовековне Србије која се толико осетно „клацка” између сопственог, левантинског, православног али и оријенталног традицијског ослонца и нових вредности и начина живљења који су западне провенијенције. Увиђамо, према томе, извесну блискост са тема- 
ма из „Швабице”, само што је у „Вертеру”, рекло би се, наглашенији пародични третман истих и иронични отклон приповедача. Блискост се огледа и у одабиру интелектуалца за главног лика - овде је то Јанко - чиме је омогућено за Лазаревића толико карактеристично тематизовање конфликта између емоционалних димензија индивидуе, овде садржаних у Јанковом чудном флерту са Маријом, и друштвене залеђине те индивидуе.

Пажњу ћемо, зато, усредсредити на делимично комичну Јанкову идеолошку преоријентацију у завршници приповетке. Она је посебно мотивисана двама моментима у сижеу: Недићевим поклањањем Гетеовог романа Jади младог Вертеpa Јанку, те кратким писмом којим поручник Васиљевић обавештава Маријиног мужа, Младена, о афери коју она започиње. Први моменат резултује подоста афектираним Јанковим поистовећивањем са судбином Гетеовог фамозног љубавног патника и самоубице, а други сусретом Младена, Катанића и Јанка за кафанским столом, којим се прича заокружује. Катанић вади из џепа Гетеовог Bертера. Неспоразум до кога долази при Младеновом и Јанковом коментарисању романа сажима у себи, у једном хуморном духу, лице и наличје доживљаја немачке књижевности, а затим уопште немачке културе из перспективе два образована Србина. Док Младен намерно травестира Гетеово романтичарско штиво и указује на лажни идеализам њиме генерисан, Јанко се налази увређеним и доста неспретно брани сопствено проналажење у Вертеровој судбини („Све што би он хтео рећи, кад би га језик служио, било би: Али сриу се не заповеда!" (Лазаревић 1958: 226).

Притом, читав разговор може се посматрати као интерполирана литерарна расправа са комичним покрићем. Младеново дистанцирање од, слободно казано, идеологије коју пропагира Гетеов Вертер, прелази у глорификацију српске културе, то јест у неки вид национализма, што је у вези не само са хердеровском матрицом о особености националних духова, за коју Ентони Смит допушта и одредницу „културног популизма” (Smit 1998: 119), већ поново са оном источњачком претпоставком о нацији као иманентној заједници рођења. У прилог овоме стоји и Младенова реплика: „Бре, не био ти какав здрав Шумадинац - он би њега на брзу руку излечио. [...] Камо мати, жена, деца, кураж, отаџбина, част...?" (Лазаревић 1958: 226-227). Катанићево декламовање из Горског вијенца само ће поспешити скоро па незауздано слављење ,здравља” балканске културе, услед чега ће Јанко поклекнути, као нагло пробуђен, и сам дати предност Младеновим идејама, а имплицитно препустити Марију као симболички „плен” због ког се, заправо, и потегла читава расправа.

У епилогу приповетке, а што је могуће читати као иронију, види се „нови” Јанко, трезвен и имун на „швапске бљувотине”, занесен српском историјом. Као и у „Швабици”, феномен друштвеног (патријархални етос) потире феномен приватног (љубав према жени), али је ово сучељавање немогуће доживети као трагично. 
3.

Приповетка „Ветар” биће овде разматрана не толико због оних националних представа - јер такве немају значајнију функцију на значењској равни текста - већ због Лазаревићевог опсесивног проблема који је у њој најпотресније сажет, а који се пре свега односи на оно што је у претходној анализи постављено као рестриктивна инстанца патријархалне културе. Услед изузетне мотивске и значењске комплексности „Ветра”, акценат ће надаље бити стављен на однос између главног јунака и његове мајке, не би ли се покушала расветлити тема едипалности из перспективе пројекције о другом ком се појединац повинује.

Бавећи се овим питањима, Зоран Глушчевић у есеју „Едипално у делу Лазе Лазаревића” указује на нужност посматрања „Шбавице” и „Ветра” као инте-гралне психолошке структуре и говори о „Књижевно-структурној симбиози" (Глушчевић 1998: 245), што је дубоко тачно примећено. Такође, може се прихватити његова оцена по којој су различите ствари у двема приповеткама екстериоризоване. У „Швабици” се не образује један рестриктивни члан, већ се све преплиће - завичај, култура, нација и породица. „Ветар” доноси другачије решење, и мајчинска фигура као да сабира у себи све рестриктивне одлике патријархалног света. Када се томе придода едипалност као доказива појава у књижевном свету главног јунака, готово силогистички се поставља питање: може ли се лик мајке доживети као двоструки супституент, или као означитељ колико недостатка очинске фигуре, толико лебдеће претње једне посесивне културе? Темељна претпоставка одавде изведена гласила би, дакле: мајчино деловање у „Ветру” није узроковано само њеном посесивношћу услед едипалног односа, већ и услед таквих културних норми које јој налажу да „сачува” сина у њиховим границама. Но, ваља се обратити самом тексту.

Већ у експозицији, Јанко, у улози уведеног наратора кроз кога је фокализовано све што се у приповеци дешава, апотеозира мајчинство, али не било које, будући да каже: „Боже мој, како су биле велике наше матере!” (Лазаревић 1958: 246). Једним атрибутом потцртано је да он, макар свесно, ужива осећање припадања конкретној, матичној заједници. Сличан исказ, Јанко ће у више наврата варирати. Оно што је изузетно у „нашим матерама”, заправо спада у нека од битних обележја и пожељних особина из патријархалног корпуса: традиционализам, принципијелност, одлучност, одважност и религиозност. Одатле произилази да Јанко у својој мајци не види само надређену женску фигуру, него и ону која, силом прилика, преузима функције одстутног оца. Неколики описи нежности коју мајка према Јанку показује, заједно са његовом скоро па инфантилном комоцијом којом понуђену нежност прихвата, заиста поседују симптоме едипалног односа.

Но, имајући у виду уметничко дејство интегралне приповетке, пре би се могло закључити да је опстајање мајчине посесивности у склопу поменутог односа израженије. Јер лик Јанка, што је врло поредиво са Мишом из „Швабице”, онеспособљен је не с обзиром на властите вољне поступке, него превасходно 
захваљујући деловању спољног ентитета, саображеног у мајци. Овом ентитету могу се приписати прерогативи лакановског великог Другог јер се у појединим сценама - попут оне у којој мајка, као вођена неком страном силом док инсистира на „моралу” из алегорије о Арханђелу и двама црвима - испољава удео несвесног у двосмислености свог говора.

Одиста, мајчина улога у „Ветру” носи нешто мутно и тешко сводиво на дискурс именовања, без обзира на сцене идилски интонираног живота са сином, какве налазимо на почетку приче. Она као да је израз или форма непознатог, узнемирујућег, готово дијаболичног ентитета који, или у циљу остварења скривених жеља и нагона, или зарад испуњења неког вишег принципа, за свога сина поништава могућност слободног избора. Замаскиране изјаве одобравања синовљеве женидбе, они двосмислено артикулисани коментари, додатно боје овај лик нечим чудним и чудноватим, не само у његовој сериозности, већ и управо супротно, у поовском смислу речи (,The Angel of the Odd”) 3 . Да ли је њена сила поредива са неухватљивим дејством отаџбине у „Швабици”? Донекле би се могло одговорити потврдно.

И у Јанковом удесу поново се јавља другост која не успева да се савлада или која не успева да, на овај или онај начин, срасте са њему иманентним светом жеља које у суштинском смислу не могу бити испуњене 4 . Но, овде је проблем додатно закомпликован сужавањем визуре на нездраве односе у породици, или чак у двема породицама. Јер, треба то рећи, онакво алегорично и злокобно финале „Ветра” не говори у прилог апологији здраве патријархалне заједнице, на чему је у старијој критици инсистирано, напротив - оно целокупан Јанков случај и његов живот са мајком оставља додатно затамњеним, ишчашеним, можда и необјашњивим.

Са својим „моралима”, са „озбиљним” изразом који преузима кад год се потегне питање Јанкове женидбе, најпосле са неразмрсивим утицајем који на њега има ${ }^{5}$, мајка, наравно симболички, поседује исту ону регулативну димензију коју јунакова свест о националној припадности и завичајном пореклу има у „Швабици”, с том разликом што је у „Ветру” ова димензија погубнија по јунака. Уколико би се истовремено посматрале имаголошке одлике мајчиног лика и њена веза за едипалношћу главног јунака, приметило би се да је по среди сасвим сродна хипертрофија или извитоперење слике о мајци. Она је, парадоксално, и оно што би по налогу патријархалне традиције морала да буде - чувар, и оно што иста традиција дисквалификује - узрок несреће потомства захваљујући осујећењу

${ }^{3}$ Када је реч о дометима психоналалитичког читања приповетке „Ветар” и могућностима образлагања фројдовског unheimliche ефекта као темељне саставнице њене структуре, видети: Милосављевић Милић, Снежана. Болест, слепило, потискивање - Ветар Лазе Лазаревића. Огледавања: Лаза Лазаревић - Сима Матавуљ. Ниш: Филозофски факултет, 2014, стр. 81-95.

${ }^{4}$ Овакав случај призива у сећање извод из Лаканових Списа: „, Ако сам рекао да је несвесно беседа Другог са великим Д, то је зато да бих назначио оностраност у којој се признање жеље везује са жељом за признавањем (Lakan 1983: 184).

${ }^{5}$ Сам Јанко при крају приповетке примећује: „Кад јој погледах у очи, видех нешто огромно велико, али не разумем ни оволишно" (Лазаревић 1958: 272) . 
љубавне везе, а затим, евентуално, и брака као једне од најстабилнијих институција поменуте традиције.

Закључак. На примеру три изабране приповетке сличног тематског језгра („Швабица”, „Вертер”, „Ветар”), а с освртом на битне пасаже из других Лазаревићевих приповедака, у раду је апострофирана деликатност и помно осмишљавање метода којим овај аутор слика другост: најпре националну, а затим социјалну, односно родну. Указано је и на реверзибилност тог метода: на неизбежно откривање слике о сопству која се приписује главним јунацима. Најзад, посебно битном показала се чињеница да описани метод упадљиво предодређује психолошке и симболичке слојеве Лазаревићевог књижевног света.

\section{ИЗВОРИ}

Лазаревић 1958: Л. Лазаревић, Приповетке, Нови Сад / Београд: Матица српска / СКЗ.

\section{СЕКУНДАРНА ЛИТЕРАТУРА}

Вукићевић 2011: Д. Вукићевић, Анархија текста: огледи о српској књижевности 19. века. Београд: Службени гласник.

Гвозден 2001: В. Гвозден, Полазишта и циљеви имаголошког проучавања књижевности, Зборник матице српске за књижевност и језик XLI, свеска 1-2 (2001): 211-224.

Глушчевић 1998: З. Глушчевић, Кьижевност и ритуали, Београд: Нолит.

Живковић 1994: Д. Живковић, Европски оквири српске књижевности $V$, Београд: Просвета.

Константиновић 2006: 3. Константиновић, Компаративна имагологија балканског и средњоевропског простора, у: Миодраг Матицки (ур.), Слика другог у балканским и средњоевропским књижевностима, Београд: Институт за књижевност и уметност, 2006.

Lakan 1983: Ž. Lakan, Spisi (izbor), Beograd: Prosveta.

Милосављевић Милић, Вукићевић 2014: С. Милосављевић Милић, Д. Вукићевић, Огледавања: Лаза Лазаревић - Сима Матавуљ, Ниш: Филозофски факултет.

Pageaux 2009: D. H Pageaux, Od kulturnog imaginarija do imaginarnog, u: D. Dukić i dr (ur.), Kako vidimo strane zemlje: Uvod u imagologiju, Zagreb: Srednja Europa, 2009, str. 125-150.

Раичевић 2007: Г. Раичевић, Лаза Лазаревић јунак наших дана, Нови Сад: Академска књига.

Smit 1998: E. Smit, Nacionalni identitet, Beograd: Biblioteka XX vek. 
Supek 1986: R. Supek, Živjeti nakon historije: prilog dijalektici oslobođenja. Beograd: Rudi Supek/Slobodan Mašić. < http://imagologica.eu/aboutimagology > приступ: 9. 4. 2019.

Milan D. Vurdelja

\section{OTHERNESS THAT CAUSES FORCED TREPIDATION: IMAGOLOGICAL ASPECTS OF LAZA LAZAREVIĆ'S SHORT STORIES}

\section{Summary}

Diverse scientific area of imagology as an autonomous discipline of comparative studies was activated in this paper through the examination of literary problems in selected stories of Laza Lazarević. The main hypothesis was that national, class and other images in the fiction of Laza Lazarević contain important layers of meaning. Therefore, writing methods that portray otherness were highlighted in analysis, which led to a conclusion that they play a crucial role in the poetics of Serbian realistic writer.

Key words: Laza Lazarević, realistic (short) story, images of otherness, national identity, mother culture, strangeness. 